\title{
To Veil or Not to Veil: Gender and Religion on Al-Jazeera's Islamic Law and Life
}

\author{
Dima Dabbous-Sensenig \\ Director, \\ Institute for Women's Studies in the Arab World (IWSAW) \\ Lebanese American University
}

Keywords: $\quad$ critical discourse analysis, Al-jazeera, talk shows, religion, gender, Muslim dress code

\begin{abstract}
This article uses critical discourse analysis (CDA) in order to analyse the discussion of the Muslim dress code (commonly referred to as the hijab) on Al Jazeera's religious talk show A-Shari'a wal Hayat. Between 1998 and 2003, several episodes dealt with the Turkish and French ban and the 'issue' of the headscarf, most of them hosting prominent religious scholar Youssef Qaradawi. Drawing mostly on Fairclough's critical analytical approach to the media, I will examine, at the micro- or local level, key linguistic strategies and rhetorical arguments deployed by participants (mostly Qaradawi, and to a lesser extent, hosts and viewers) in order to justify their position concerning the nature of the Muslim dress code. This in depth textual/local analysis will be supplemented with a brief analysis at the macro- or global level, which will look at the overall structure of these episodes in order to see the extent to which dominant positions privileged by participants at the micro level are also reinforced by the superstructure of the episodes themselves. Throughout, an intertextual analysis will be used in order to study which religious discourses from the larger socio-cultural context are drawn upon in Al-Jazeera's discussion of the bijab. The purpose of this multi-levelled analysis is to answer the following questions: Which religious discourses on the bijab are privileged by those talk shows? Are there any differences in the range of opinions covered by the various episodes dealing with the same issue? How are the various positions, when they exist, manifested at the local/global levels of analysis? Most importantly, what do these discussions on the hijab tell us about Al-Jazeera's self-confessed editorial line ('the opinion and the other-opinion') concerning one of the most controversial religious topics for Muslims?
\end{abstract}

\section{Introduction}

The present article takes to task Al-Jazeera's self-advertised mission statement of providing its viewers with the 'opinion and other-opinion'. It seeks to study the extent to which this motto, which has been found by various studies to describe the station's popular political talk shows, also applies to Al-Jazeera's religious talk shows. Indeed, these shows, especially the popular A-Shari'a wal Hayat (Islamic Law

Westminster Papers in Communication and Culture (C) 2006 (University of Westminster, London), Vol. 3(2): 60-85. ISSN 1744-6708 (Print); 1744-6716 (Online) 
and Life) remain comparatively neglected in existing research about Al-Jazeera programming. Numerous studies of this Arab satellite 'phenomenon' which has 'scooped the world' have concentrated on the station's most popular political talk shows, and have demonstrated the relatively independent, often highly adversarial - albeit sensationalist - character of these shows (Ayish 2005; Zayani ed. 2005; El Nawawi and Iskandar 2002; Al Shammari 1999). For instance, Al-jazeera's flagship political talk show and arguably its most popular and controversial, Al-Ittijah AlMu'akes (The Opposite Direction), is found to exemplify best Al-Jazeera's break away from traditional Arab journalism which is marked by a stale, bland, one-sided, and un-engaging handling of news and public affairs in the Arab world. According to these studies, this and other live political talk shows that openly discuss sensitive and controversial issues distinguish Al-Jazeera as a 'forum for resistance', a 'platform for political dissidents' which until it emerged were virtually excluded from Arab screens. These shows, as Zayani puts it, allow Al-Jazeera to 'venture into a realm of open discussion rarely attempted by other broadcasters in the region' (Zayani 2005, 2).

In order to evaluate the extent to which the same can be said about Al-jazeera's religious talk shows, I will study key excerpts from all those episodes of Al-Shari'a wal Hayat which dealt entirely or partially with the nature of the headscarf. I chose the Muslim headscarf - commonly though erroneously referred to as the bijab ${ }^{1}$ and by extension the Muslim dress code as a case study not only because it is considered to be a basic aspect of the Islamic faith by many Muslims, and was subject to two highly politicised bans within a short period of time (one in Turkey and one in France), but also because of the intricate web of symbolic meanings (religious, ideological, and societal) woven into it first as a result of Western colonisation and later of globalisation (Ahmed 1992, 144-68). Indeed, the Muslim veil in the last decades increasingly became a 'symbol of the validity and dignity of Muslim tradition as a whole', and a core aspect of 'Islamic authenticity' (Freyer Stowasser 1997, 100 and 104).

Largely based on Norman Fairclough's version of critical discourse analysis (CDA), as applied to the media (1995), and M.A.K. Hallyday's systematicfunctional grammar (1985), the study will, in specific, seek to answer the following questions: Which positions gleaned from the currently existing, divergent views on the hijab are favoured by Al-Shari'a wal Hayat? To what extent are these positions non-dominant or oppositional? Are there any differences in the range of opinions covered by all episodes dealing with the same issue? If yes, how are these different positions manifested at the various levels of analysis (local/micro, global $/ \mathrm{macro}$, intertextual levels, and so on)? Most importantly, what do these discussions on the hijab tell us about Al-jazeera's self-confessed motto ('the opinion and the counteropinion') and the nature of debate on gender and religion in the station's talk shows concerning one of the most controversial religious topics for Muslims? 


\section{Critical Discourse Analysis (CDA): Suggested Theory and Method}

Critical discourse analysis (CDA), as a fairly recent field, is not only marked by a divergence of theoretical and methodological approaches, but also by disagreement over the very meaning of 'discourse' (Georgakopoulou and Goutsos 1999; Titscher et al. 2000). Despite these differences, all writers in the field share several key concerns, some of which are especially pertinent to the present study of the existence of oppositional or counter-hegemonic views on religion in Al-Jazeera talk shows. CDA for instance is mainly interested in the relationship between language use in social life on the hand, and social structure on the other. It is concerned with both text and context, or text in context, where language is viewed as being dialectically constituted by and constitutive of social reality (Fairclough 1995, 5455). More specifically, the concern is with the connection between use of language and power, or the ways in which texts 'encode relations of power, authority and status' (Deacon et al. 1999, 149).

Though no single theoretical framework for the study of the manifestation of power relations in language is adopted by all critical discourse analysts, I find Gramsci's dual concepts of commonsense and hegemony particularly relevant for my own analysis of the competing definitions of the bijab on Al-Jazeera talk show episodes studied in this paper. On the one hand, commonsense is the popularising of particular definitions of social reality (ideologies), with ideological power, as the 'power to signify events in a particular way' (Hall 1995, 356), consisting largely of 'making a meaning stick' in order to sustain existing inequalities in relations of power and authority in society (Thompson in Deacon et al. 1999, 325). This is achieved mostly through 'naturalisation' of these specific meanings or definitions, i.e. by rendering invisible their social constructedness. On the other hand, the concept of hegemony duly recognises that ideologies (as commonsense) are not rigid and forever stable, despite attempts to appear so. Rather, ideologies are inherently 'fraught with their own internal contradictions' and hegemony, as a process of social control by dominant groups through commonsense, is never entirely won, but it is continually fought for and resisted (Deacon et al. 1999, 324). These concepts allow us to see the media as complex fields of mediated political discourse and practices, and as sites for hegemonic struggle where subordinated groups are capable of airing counter-hegemonic views. This non-deterministic conceptual understanding of the complexity of media among other 'ideological' institutions, allows a differentiated analysis of the workings of dominant ideologies and 'offers a strategic guide to the ways in which major transformations within society may be most successfully accomplished and to the crucial role of...media practices in bringing about such transformations' (Masterman 1985, 197).

Methodologically speaking, this study of media texts as sites for struggle over competing definitions of social reality is mostly achieved by examining the role 
played by language in legitimising certain social relations and hierarchies of authority, and by assuming that relations of power are embedded in language structures (as manifested in lexical and grammatical choice, modality, metaphor, and so on). As such, CDA seeks to 'look[...] at language with language' (Deacon et al. 1999, 149). In that respect, Halliday's (1985) systematic-functional grammar proves quite central to such an endeavour. Recognising that the relation between the meaning and the wording is not an arbitrary one, Halliday argues that functional grammar is intended to bring out how the form of the grammar relates to the meanings that are being encoded (xvii, emphasis mine), since a difference in meaning entails a difference in form and vice versa. He also adds that a higher level of achievement than the mere understanding of a text is a 'contribution to the evaluation of the text' (Halliday 1985, xv, emphasis in original). This entails an interpretation of not only the 'context of situation' and 'context of culture', but also of 'how the linguistic features of a text relate systematically to the features of its environment, including the intentions of those involved in its production' (Ibid, $\mathrm{xv}$-xvi). In other words, the linguistic choices made in texts can have ideological meaning.

\section{Discourse in Context(s)}

Perhaps what distinguishes most critical discourse analysis or CDA from traditional content analysis, and even the more qualitative sociolinguistics and conversation analysis is the way in which it links the study of text with context. Many CDA analysts indeed argue for the need to examine texts on at least two contextual levels: the local or 'micro-level' and the broader context or 'macro-level' (Titscher et al. 2000, 27). The microanalysis seeks to identify syntactic and lexical as well as rhetorical features of the text (Van Dijk 1988, 26-27). Analysis of the macro-level relates to the overall content (or thematic structure) and overall form (or schematic structure or superstructure) of a text - such as a single news report in a newspaper. For Fairclough and other CDA analysts, though, other levels need to be added to provide a fuller context to the analysis. Central to this multi-contextual CDA approach, for instance, is an intertextual analysis that can complement linguistic analysis by helping to reveal, among other things, the interface between language/text (in this case the key clauses in the excerpts studied) and language use or discourse (religious discourse/s drawn upon in these clauses)(Fairclough 1995, 61).

This multi-contextual approach allows us to understand how media discourse can help produce and reproduce unequal power relations. But more importantly, as Fairclough argues, it foregrounds the diversity, complexity, and heterogeneity of media practices, another main focus of Fairclough's fully integrated framework for media discourse analysis $(1995,30)$. Indeed, Fairclough's major concern is less about showing how (usually unequal) social relationships and processes are 
reproduced at the micro-level of texts, than about accounting for the ways in which 'shifting language and discursive practices in the media constitute social and cultural change' (Ibid 29, emphasis mine). This objective acquires more urgency in the context of an Arab media landscape which has been undergoing major structural changes starting with the emergence of the first pan-Arab satellite stations in the early 90s (Dabbous-Sensenig 2005). Indeed, a major task if not challenge when studying Arab satellite programming is to document to what extent these structural changes have actually resulted in generic, thematic, and discursive changes in Arab media output.

\section{Analytical Breakdown of the Study}

Drawing largely on Fairclough's version of CDA (1995) and Hallyday's systematicfunctional grammar (1985), I will study those episodes from Al-Shari'a wal Hayat that deal entirely or partially with the bijab ${ }^{2}$. The main focus will be on the linguistic analysis of texts at the micro or local level, particularly the ideational/representational functions of key clauses or constructions in these episodes, with an attempt to see this analysis in context. Knowing that the very conceptualisation of context is problematic (i.e. how much context is sufficient context) (Cicourel 1992, 309), I will include, considering limitations of space, those contextual elements that can, as much as possible, shed more light on the nature of the 'religious debate' in Al-jazeera talk shows. To start with, the linguistic analysis will be complemented with an intertextual one that focuses on 'discourse representation', 'of how the speech and writing of others is embedded within media texts' (Fairclough 1995, 75). This specific aspect of intertextuality will require, among other things, an understanding of the existing spectrum of religious discourses that exist in the Arab-Muslim wider social context. Therefore a brief review of both orthodox and non-orthodox/alternative religious discourses in the Arab-Muslim world, particularly on the nature of the Muslim dress code, will precede the textual/representational analysis of the bijab-related episodes. Following the micro-level analysis, there will be a brief analytical section dealing with another immediate context: i.e. the global context of the episodes (thematic and schematic structures of single episodes). Finally, examples from other, nonreligious Al-jazeera talk shows dealing with the hijab will be drawn upon to make methodological and theoretical observations about the wider institutional context of production (i.e. Al-Jazeera as an Arab satellite broadcaster), and the role of this major satellite broadcaster in mediating discursive and social change in the Arab world. 


\section{The Hijab in its Socio-religious Context}

Since 1989, when two French Muslim teenagers (Alma and Layla Levi) were expelled from school for refusing to remove their headscarf, as well as a similar attempt in Turkey in 1998 to ban the headscarf, Muslim lay people in the Arab world have been increasingly confronted with a debate related to the role and nature of the bijab (Muslim headscarf) which they had believed was 'a given', a clear command from God as enunciated in the Qur'an. When the French parliament adopted, on February 10 th 2004, a bill banning the hijab and other 'conspicuous' religious symbols in state schools, Muslim communities worldwide were outraged. The French ban, in addition to fuelling the debate on anti-Islamic discrimination, the nature of secularism and religious freedoms in Europe, re-ignited an older, preexisting discussion within the Muslim world on the nature and role of the hijab in the life of a Muslim woman: is the bijab a religious obligation for Muslim women to start with, and if yes, how should a Muslim woman cover herself?

Though the debate itself is not new, the last 15 years have witnessed a proliferation of newspaper articles, television talk shows, and books on the bijab, covering most of the spectrum between two dominant orthodox Muslim positions which agree that covering the hair or bijab is a command from God, but disagree on the obligation of wearing it under all circumstances. Another ultra-conservative position should be mentioned here, namely that which calls for niqab or complete covering of the body, including face and hands. The divergence of opinion among dominant orthodox positions was complicated by the emergence of a nonorthodox, scripturally-based Muslim 'revisionist' position, which added more confusion to the issue ${ }^{3}$. According to this position, not only are Muslim women not obliged to wear the bijab, there is actually no scriptural justification for covering a woman's hair to start with (Barlas 2002; Shahrour 1990; Baraka 2003). The most extreme expression of this position has been publicised by a leading Egyptian Muslim feminist Nawal Al-Saadawi. Though not an Islamic scholar herself, she dismisses the bijab altogether because it is 'not Islamic at all', asserting that 'nothing in Islam refers to covering the head', and that women who think they are choosing it willingly are indeed victims of 'false consciousness' and 'brainwashing' (interviewed in the Daily Star, Mach 1st 2004).

\section{Scriptural Interpretations of the Muslim Dress Code}

The purpose of the present 'contextual' section on the scriptural description of the Muslim dress code is to prepare for the discourse analysis of the bijab-related episodes, by exposing the 'commonsensical' or 'ideological' nature of the existing, dominant definition of the hijab. Indeed, as we will see later on in the micro-level analysis, only by understanding the weakness of the scriptural foundation of the Muslim dress code does it become clear that the definition of the bijab repeatedly put forth by Qaradawi and other guests in A-Shari'a wal Hayat, is little more than a 
naturalisation and popularisation of a dominant, orthodox, and, as some Muslim feminists argue, gender-biased interpretation of the qoranic verses related to the Muslim dress code.

The Muslim religious dress code for women is derived from and referred to in just two qoranic verses: verse 31, Sura 24 (The Light); and verse 59, Surah 33 (The Clans) ${ }^{4}$. In Sura 24, verse 31, the prophet Mohammad is commanded by God to:

Say to the believing women that they should lower their gaze and guard their modesty; that they should not display their ornaments [zeena] except what appear thereof, that they should draw their veils [khumur, s. kbimar] over their bosoms [juyub, s. jayb], and not display their ornaments [zeena] except to their husbands, their fathers, their husbands' fathers...

In Sura 33, verse 59, God says to the prophet:

O Prophet! Tell thy wives and daughters, and the believing women, that they should cast (draw close) their garments [jalabib, s. jilbab] over their persons. That is most convenient, that they should be known and not molested. And God is Oft-Forgiving, Most Merciful.

Reading these verses, though it is clear that there is a reference to covering some body parts (especially in 24:31), one is struck first and foremost by the absence of any explicit reference to covering a woman's hair (instead women are asked clearly to cover their zeena, translated as ornament, and juyub, often translated as bosoms). Despite the absence of any direct reference to hair in the Qoran, the 'covering' has been understood traditionally to include the hair ${ }^{5}$. Indeed, covering the hair seems to be the single lowest common denominator among the established Islamic schools of jurisprudence when it comes to those parts of the head that a Muslim woman should conceal.

Moreover, understanding of verse 31 of Sura 24 revolves around the key term zeena ('adornment', 'ornament' or even 'beauty' depending on the English translation) because it refers to that which is to be covered. Nowhere, however, does one find what God means by 'adornment', or what the qualifying phrase means (i.e. 'except what appear thereof'). In the same verse, women are also told to throw (yadribna) their khumur (a type of covering) over their juyub (often understood to mean bosoms, but sometimes necklines too). Finally, verse 59 (in Sura 33) asks women to draw their cloaks (jalabib, s. jilbab) closer to their bodies in order to be recognised and avoid being molested'. In this verse, too, the Muslim woman does not have clear indicators as to what exactly she should wear or maybe add to her regular clothing, since all she is required to do is to draw her jilbab closer to herself/body in order to identify herself. 
In sum, the qoranic foundation (i.e. 24:31 and 33:59) for defining the Muslim dress code is ambiguous, based on vague terms (zeena, khimar, jayb and jilbab) which are nonetheless key in determining what parts of her body a Muslim woman should cover (Barlas 2002; Clarke 2003; Freyer Stowasser 1997; Qaradawi 2001; Baraka 2003; Zeydan 2004).

Given the obvious ambiguity of dress-related terms in the Qoran, Muslim theologians and qoranic commentators and scholars had to resort to badith, the second most authoritative scriptural source after the Qoran, in order to 'fill the gap', explain God's words and find a 'unified', 'single' definition regarding the nature of the bijab that lay Muslim people can use. Resorting to hadith, however, entailed a different set of problems. As the body of collected reports about the sayings and actions of the Prophet Mohammad which were memorized after his death and transmitted orally for several hundred years from one person to another before being sifted for veracity by Muslim scholars and recorded for posterity, hadith contains clear but often contradictory reports on the same topic (Al-Ghul 2004; Clarke 2003; Hajjaji-Jarrah 2003).

As a result, various orthodox (male) commentators, depending on previous scholars' interpretations of the qoranic verses as well as on those reports from badith which they chose to base their interpretation of zeena on, have indeed offered different justifications for what a Muslim woman can display in public (e.g. 'apparent ornaments'). For some it was just the face, hands and feet (Zeydan 2004; Qaradawi 2001). Others argued that she could show eye-kohl, henna covering the arm till the elbow, in addition to bracelets, rings, and earrings (Baraka 2003). Some went even further, arguing that the entire female body is 'a shameful part' and therefore needed to be covered entirely with what is often referred to as niqab or burku' (Hajjaji-Jarrah 2003, 186-188; Hamid Abu Zeid 2000). Thus, rather than closing the debate on what a Muslim dress code for women should be like, hadith, as an important source of Scripture, seems to have added to the plethora of meanings surrounding the bijab, often supporting positions that are clearly irreconcilable. The absurdity of the situation is perhaps best illustrated by one prophetic interpretation that defines the jilbab as that piece of clothing which covers the entire body, including head and face save one eye to allow women to see (Baraka 2003; Qaradawi 2001).

The purpose of this section on the theological context of the Muslim dress code was to show the extent to which the very definition of that dress code is far from clear or unified in Scriptures, whether in the Qoran or in the hadith, concerning which body parts a Muslim woman should reveal or conceal. Instead, the Muslim dress code for women is inevitably varied as a result of the different interpretations made by religious scholars, depending mostly on which established Muslim schools 
of jurisprudence they belong to. It should also be emphasized that dominant orthodox interpretations of these 2 verses rarely acknowledge this ambiguity (except when they are attacking others' interpretations of Scripture), insisting instead that Muslim women cover their hair (and sometimes their face and hands) because it is a command from God, clearly spelled out in the Qoran. By contrast, progressive interpretations of the Qoran openly discuss the ambiguity of many qoranic verses and terms and the need to develop sophisticated theories of linguistics and hermeneutics as well as appropriate methodologies for qoranic exegesis. As far as the bijab-related verses are concerned, they reject the orthodox interpretations which have become 'holy'. They also openly acknowledge the lack of any direct reference to covering the hair or face, and some argue for entirely new definitions of dress-related terms based on modern theories and methodologies for interpreting the Qoran (Hajjaji-Jarrah 2003; Shahrour 1990). Thus, for Shahrour and other non-orthodox exegetes, a Muslim woman is not defying the word of God if her hair (to say nothing of her face) remains uncovered (Shahrour 1990; Khalaf Allah 1977).

\section{The Hijab According to Qaradawi: A Local/Linguitic Analysis}

A-Shari'a wal Hayat (or Muslim Law and Life) is a 90-minute religious talk show where a prominent male guest (female guests have appeared in only $1.5 \%$ of the episodes since 1998) is hosted in order to offer his religious views on a variety of topics, including the subject of gender. Some of these topics have included: Muslim banking, reform of religious education, Muslim immigrants in the West, Muslim feminism, Muslim Law and the environment and Muslim jurisprudence. The guest is usually but not exclusively a Muslim religious scholar who is interviewed live by the programme's host and then answers questions from callers. It is one of the oldest running talk shows on Al-Jazeera, and reportedly among its most popular (Shadid 2003). What is worth noting about this religious show is that unlike Al-Jazeera's flagship political talk shows such as Al-ttijah al-Mu'akes (The Opposite Direction) or Akthar Min Ra'i (More than One Opinion), it avoids the confrontational set-up altogether, hosting one guest at a time. From the outset, this distinct generic format or set-up (i.e. single guest show) sets A-Shari'a wal Hayat apart from Al-Jazeera's other non-religious talk shows whose very popularity depends on the (often sensational) debate or confrontation between at least two guests representing markedly opposing points of view. Another generic feature of this show which further distinguishes it from other talk shows is the recurrent appearance of one particular guest: Sheikh Youssef Qaradawi. Whereas other guests have been at best invited to appear twice on this show between the beginning of January 1998 and the end of 2005, Qaradawi appeared in 55\% of all episodes aired during that period and on the two episodes dedicated entirely to the bijab - an appearance that from the outset reflects the station's privileging of 
Qaradawi's (religious) voice. As we will see later on, both these generic aspects of the show, i.e. the single-guest set up and the predominant position accorded to Qaradawi, are not arbitrary choices and have ideological implications, especially concerning the dominant definition of the bijab on Al-Jazeera's main religious talk show.

Because of this a-priori privileging of Qaradawi's voice and the absence of other voices/participants on those episodes of A-Shari'a wal Hayat that dealt exclusively with the bijab, this section will not deal with the Hallidyan interpersonal function of the excerpts (a function which has to do with the construction of relations and identities among the various participants in a text). Instead, the focus will be on the representational or ideational function of the text, i.e. how events and the people and objects involved in them are represented (by the single guest Qaradawi, and to a lesser extent his host) in the linguistic choices made in simple sentences or clauses. This linguistic study will be, whenever possible, complemented by an intertextual analysis in order to bring out the various levels of meaning embedded in simple grammatical constructions and to connect linguistic strategies with the wider socioreligious context.

Three (often related) aspects of this ideational and textual analysis are especially pertinent for understanding the definition of the hijab put forth by Qaradawi on Al-Jazeera: the first has to do with the structuring of clauses or grammar; the second with lexical choice; the third with forms of argumentation or rhetorical strategies used, especially the use of metaphors. Starting with the structuring of clauses or grammatically simple sentences, one should ask what choices have been made among the various possibilities regarding process (usually realised in verbs), participant (realised in nouns or nominal groups) and other syntactical elements (such as adverbials) contained in these clauses (Fairclough 1995, 104). As Fairclough explains, this analysis of choices made in terms of process and participant types is a resource for 'spelling out how properties of and differences between discourses are realised in the language of the text' (Ibid, 105).

According to a functionalist approach to grammar, speakers - when representing something that happens - have the choice between various process types: they can represent it as an Action or an Event, as a Process or a State, and so on (Halliday, 1985). These choices or transformations, more importantly, depending on the wider socio-cultural context, may not be purely linguistic. When such choices are made systematically, they reflect the intention of the speaker and may be ideologically motivated. Two such particular, recurrent transformations are worth noting about Qaradawi's discussion of the Muslim dress code in the episodes dedicated entirely to the bijab issue and its banning in Turkey and France (the first aired on 17 May 1998; the second on 21 December 2003). In response to the central question put forth by the host about the description of the hijab in the Qoran, Qaradawi 
repeatedly said 'it is clear in the Qoran' [haza wadeh fil Qor'an] or that 'the Qoran is clear' [al Qor'an wadeb]. Another construction repeatedly used is: 'The Qoran is the one who commands it' [al Qor'an buwa allazi amara] and a grammatical variation on it ('it is a Qoranic command' [hatha amr qor'ani]). As evidence of the clarity of the qoranic commands concerning what the Muslim dress code is about and the duty incumbent on women to wear it, Qaradawi follows either one of these propositions immediately with one of the two key bijab-related verses - the same verses whose very ambiguity as we have seen earlier has resulted, historically and up to the present, in competing definitions among the various qoranic exegetes (orthodox and progressive alike) about the nature of the Muslim dress code.

In looking at the syntactical nature of these key clauses by Qaradawi, one notices first that they are 'extreme case formulations' that offer a categorical position on, or the definition of, social issues. More importantly, these formulations work to suggest that 'a phenomenon is "in the object" or objective rather than a product of the interaction or the circumstances', or as in this specific case, of human interpretation (Pomerantz quoted in Tileaga 2005, 612). To be specific, these extreme case formulations are constructed grammatically in such a way as to turn a mental process of sensing, cognition or interpretation (that can alternatively and more accurately be expressed as 'I believe/think the Qoran to be clear on this') into a state expressed as a relational process of being ('the Qoran is clear') or action expressed as material process of doing ('The Qoran commands it') (Halliday 1985). As Hallyday explains,

in a clause of mental process, there is always one participant who is human. [...] the significant feature of such a participant is that of being 'endowed with consciousness.' Expressed in grammatical terms, the participant who is engaged in the mental process is one that is referred to pronominally as be or she, not as it $(1985,108)$.

Precisely what is common and striking about these two formulations used recurrently by Qaradawi is that what is clearly a mental process which would have 'foregrounded agency, causality and responsibility' (i.e. the human act of interpretation) has been worded differently, in ways that effectively backgrounded them (Fairclough 1995, 113). In the first case formulation - 'the Qoran is clear' the Qoran is in a state of being, with the attribute 'clear' non-problematically and without any logical justification ascribed to it ${ }^{6}$. In the second formulation - 'the Qoran commands it' - the Qoran is Actor/logical Subject of a material process of doing (Hallyday 1985, 102). As such, these formulations grammatically elide the issue of human agency or responsibility, and the fact that religious scholars have to actively engage in interpreting the Qoran (or those ambiguous verses in it) in order to bring out what they are convinced is a 'clear' meaning, as is the case in the not- 
so-clear bijab-related verses: if the Qoran is clear on the bijab-related verses, as Qaradawi asserts, there can only be a single meaning for these verses - the one put forth by him - and therefore no further interpretation is involved or is required.

An intertextual analysis is especially pertinent here, revealing how these formulations or structuring of clauses are not exclusively matters of individual choice, but can also embed a specific form of argumentation basic to the dominant, orthodox religious discourse(s) in the Arab and Muslim world. Indeed, Qaradawi's straightforward, simple clause formulations articulate or call upon a complex, interrelated set of dominant orthodox religious discourses of Sunni Islam: the discourse of Sunni Muslim jurisprudence (establishing, in matters of faith, the utmost authority of formally trained religious scholars), the discourse of acceptable qoranic exegesis (with the central, mediating role of these scholars in making it accessible to lay people), and the discourse of Muslim piety (whereby it is the religious duty of Muslims to accept, without questioning, the Qoran as clarified by any of the established schools of Muslim jurisprudence). Since the demise of the rationalist school of qoranic exegesis defended by the Mu'tazilah by the middle of the $9^{\text {th }}$ century A.D., the Arab-Muslim world has been (and continues to be) dominated by the Malikites, Hanbalites, and other literalist, traditionalist (and mostly anti-rationalist) schools of Sunni Islamic jurisprudence that believe in the Qoran as the uncreated, eternal 'embodiment of Divine speech' (Fakhry 1997, 20). Whereas the Mu'tazila staunchly advocated the method of interpretation (ta'wit) through rational discourse, especially as applied to those qoranic passages deemed ambiguous, the literalists did not. The latter instead clung to the explicit meaning of the sacred text (as they understood it), insisting that belief in this meaning is a 'religious obligation and questioning it is a heresy' (Ibid, 24). The defunct rationalist discourse, more recently resuscitated by progressive Muslims, is best exemplified by the pre-modern theologian Ghazzali through his 'self-positioning' when putting forward what he sees as his own understanding of Islam (Safi 2003, 19-23). The orthodox schools of jurisprudence, by contrast, continue to favour a normative approach to Islam, and legitimise their own interpretations by postulating 'the perfect equation of exegesis' with the contents of the Qoran itself (Mohammad Arkoun in Barlas 2002, 39), or by conflating interpretation with revelation (Barlas 2002, 53). Thus, by consistently putting forth statements such as 'Islam teaches us...' and 'God says...' which deny human agency in the reading of sacred texts (Safi 2003, 21), they 'sacralize' their own exegesis (Barlas 2002, 55). This strategy has the dual effect of de-legitimising alternative interpretations of Scriptures, and of forcing lay Muslim people to readily accept orthodox interpretations, since rejecting them would amount to a 'heretic' rejection of the 'Word of God' itself. Ironically, each one of these orthodox schools speaks in the name of a universal, immutable Islam based on 'clear' Scriptures, knowing the very existence of these various schools is a testament to the impossibility 'at any time to defend one understanding of Islam as definitive' (Esposito and Voll 2001, 156). 
It is in reference to this latter camp that Qaradawi's extreme case formulations on the bijab ('It is clear in the Qoran' or 'the Qoran commands it', etc.) can be best understood: more than mere grammatical choices, they are both rhetorical and ideological. They are rhetorical because they are calculated to win over audiences with his own interpretation (Gill in Van Dijk 1997, 167). They are 'stock devices' that are 'rhetorically self-sufficient' or 'clinching' (Augustinos et al. 2005, 320) in that they reflect, without further need for any logical evidence, commonsense maxims pertaining to (misogynist) orthodox Sunni discourses on women in Islam. These formulations are, furthermore, ideological or hegemonic because they support, through religious consensus and public consent, existing socio-religious power relations. They conveniently 'close' the polysemic meaning of Islamic Scriptures and de-legitimise any alternative, non-misogynist interpretations or 'rethinking' of religious tradition which might threaten existing structures that are favourable to dominant (male) religious authorities and those states dependent on them for their hegemony (Barlas 2002, 75).

Ironically, despite his insistence on the clarity of the qoranic text when defending his own favoured position on the hijab, Qaradawi had no qualms laying bare human agency involved in understanding the Qoran when challenging others' oppositional interpretations of these same 'clear' verses. In the 1998 episode, following his assertion that the Qoran clearly says that a woman should cover everything except her face and hands, Qaradawi is asked by the host for his opinion about 'those who say that hijab is decency and not what covers a woman's hair or body, and who say that there is no qoranic text that dictates the covering of the head, and that the covering is intended for the neck and not the head'. Here, Qaradawi is forced to acknowledge the issue of interpretation of the bijab-related verses, specifically the ambiguous meaning of the key term 'zeena' (or adornment). No longer able to claim that 'it is clear in the Qoran', he concedes that the Muslim dress code (as total covering except face and hands according to his definition) is actually the result of 'consensus' among Muslims. What was established earlier as being 'clear' in the Qoran - and consequently not necessitating the consensus or ijma' of the community of religious scholars - suddenly and non-problematically becomes a matter of 'consensus'. This ideologically powerful doctrinal concept of consensus (Barlas 2002), through verbal 'overkill' and a series of extreme case formulations and expressions of modality that mask the subjectivity of the views put forth, was thus alternatively deployed to convince the interlocutor/audiences about the universality and 'objectivity' of Qaradawi's specific interpretation of the hijab (see excerpt below) ${ }^{7}$. After the host's subsequent question, however, Qaradawi immediately returns to his initial position/formulation, insisting once again that the dress code is 'a clear matter'. The following excerpt from the 1998 episode with Qaradawi's repying to his host's questions concerning non-orthodox interpretations of the bijab is worth quoting in full: 
Qaradawi: This 'adornment' they disagree over, at best it means the showing of the face and hands and these things, and some have added the feet, but there isn't, and then....as I told you it is a consensus [ijma]. This consensus is not just a theoretical consensus, it is a theoretical jurisprudential [fuqby] consensus linked to a practical consensus which makes it the most important type of consensuses. It is a theoretical and practical consensus which was agreed upon by the entire community [umma], private and public, religious scholars and peoples, this is the consensus of the community with all its factions, no one can come up and speak as he pleases, this is not considered...

Mansur: (interrupting)... but how can one respond to him [i.e. the person with an alternative definition of hijab]? He says what he says and is listened to by the gullible and the media outlets are at his disposal to promote what he is saying. So now how can one respond to these things?

Qaradawi: I told you this is it. This is a clear matter. Islamic Law (Shar') established the specifications of the legal dress code (zay shar'ee)

Mansur: Yeah...we want to know what these specifications are.

Qaradawi: What these specifications are? The first of these specifications is to cover the entire body except the face and hands. The battle here is whether the face must be covered or not.

This exchange offers rich material for an ideational and textual analysis, however, for lack of space, I will limit myself to a few observations concerning some key grammatical and rhetorical strategies deployed in order to favour a specific construction of the bijab. First, notice the use of the pronoun 'they' in the first line of the excerpt to refer to those who have an oppositional, less restrictive interpretation of the hijab based on Islamic Scriptures (no where earlier are we told who 'they' are). Moreover, by saying that 'they' (and not 'we', for instance) disagree over the term zeena, Qaradawi seems to distance himself from this disagreement, as if to say he does not share it (and therefore it is not to be taken seriously). Earlier in the episode, a deictic element, the demonstrative 'those' [ $h a^{\prime}$ 'ula'] is used, without any reference to the 'class of things' (in this case the group of people with alternative qoranic interpretations) it should grammatically be referring to (Halliday $1985,160)$.

Similar to their usage in the English grammar, pronouns in Arabic are not used separately from the 'class of thing' or people or objects they refer to, which are normally introduced in the same clause or complex of clauses or in a previous sentence. In the bijab-related episodes, the pronoun 'they', when referring to alternative, progressive interpreters of the Qoran, always stood alone, not referring to any clearly identifiable group of people or individuals. Moreover, in spoken 
(colloquial) Arabic, the grammatical choice of using a deictic element (expressing proximity to the speaker such as this or that person or thing), as a substitute for the 'class of things' it refers to instead of having it precede it, works culturally as a distancing device and as an expression of disrespect towards those singled out by the deictic element. In both cases (i.e. whether using the Subject/Actor pronoun 'they' without knowing whom exactly it refers to, and the use of the demonstrative 'those' independently of the 'class of things' it should precede), we have grammatical choices systematically made in order to annihilate or render invisible the 'other' and his/her opinion, literally by not referring to him/her except as a pronoun. Indeed, the group of people referred to in the above excerpt remained un-named/anonymous throughout the episode, and were described instead by Qaradawi as 'people off the street' [nas men 'ard a-ttarik]. The same linguistic strategy was repeated in a later episode that dealt partially with the issue of the bijab (20 March 2005). In this episode, Amina Wadood - the famous or rather infamous Muslim American feminist because she lead, in defiance to Muslim orthodoxy, a mixed-gender prayer in a mosque - and other Muslim scholars and qoranic exegetes with similarly alternative, progressive interpretations of the Islamic Scriptures were also referred to by Qaradawi with the lone deictic 'those' [ha'ula'], again used independently of its 'class of things', in order to connote utter disrespect towards those he was referring to.

In the 1998 episode this grammatical 'annihilation' of the 'other' was reinforced by a lexical one. This is evident first in the host's lexical choice during his 'reporting' on liberal interpretations of the bijab by some people, prompting the abovementioned response by Qaradawi. According to Mansur, these people (whom he also refers to exclusively with the deictic 'those') 'manipulate interpretation', influence 'the gullible', and are successful in 'promoting' their views through the media. Through his lexical choice (i.e. 'manipulate' instead of 'put forth', 'gullible' to refer to 'viewers' or 'readers' and so on), Mansur framed the oppositional discourse on the bijab negatively. Apparently not keen on maintaining an impartial stance towards non-restrictive interpretations of the hijab, he positioned himself on the side of Qaradawi throughout the episode, affirming and elaborating on the scholar's views and shunning the provocative, adversarial style which, for instance, made moderator Al Qassem and his show The Opposite Direction so popular (and controversial). This (very brief) analysis of lexical 'framing' when studying the varied discourses available in a media text is also important because it 'draws attention to how surrounding features of the reporting discourse can influence the way in which represented discourse is interpreted' (Fairclough 1995, 83).

I come now to another key linguistic strategy repeatedly deployed by Qaradawi in his discussion on the nature of the Islamic dress code: i.e. the use of metaphor. When people represent the world around them, there are several linguistic choices or 'alternative ways of wording any social practice' available to them (Ibid, 114). 
These choices, as we have already seen, can be a matter of grammar or vocabulary. A third choice may be the use of metaphor, such as referring to the killing of a group of people as 'holocaust' or 'extermination' (Ibid, 109). Traditionally, figures of speech, including metaphor, were identified for their aesthetic or literary appeal in texts. Recent studies, however, have suggested that metaphor plays a much larger role than mere 'ornamentation'. On the one hand, metaphorical applications can be socially and even ideologically motivated, with 'different metaphors correspond[ing] to different interests and perspectives' (Ibid, 94). Not only that, metaphors present 'a particular view of reality by structuring the understanding of one idea in terms of something previously understood' (Gill 1997, 173). This particular understanding of metaphor recalls the centrality of an intertextual analysis to the study of texts.

Throughout the 1998 episode, a recurrent metaphor used by Qaradawi was the 'battle metaphor'. He insisted early on that the 'battle around the bijab' is 'whether the face must be covered or not', and rejected the initial framing of the debate put forth by the host's opening question (i.e. whether a woman should cover her hair or not). In the same episode, he introduced a related 'war metaphor', referring to the West as 'the conquering civilisation'. In the March 5 ${ }^{\text {th }}, 2000$ episode, Qaradawi reiterated the 'battle on bijab' metaphor and referred to the act of relinquishing the bijab as an act of 'deviance' [inhiraf] undertaken by Muslim women under the 'corrupting influence of the West' [al-gharb wa fasadob].

Intertextually, the battle/war metaphor is indeed a culturally and ideologically potent metaphor. It evokes a dominant theme/trauma in Arab-Muslim popular consciousness, one that is closely related to early European colonialism and its newest re-incarnation in the Israeli occupation of Palestine and the American invasion of Iraq. More importantly, it is closely associated with the modern resurgence of 'Islamism' as a 'kind of moral rearmament in which women are spearheading the construction of a new social order' (Yvonne Haddad in Freyer Stowasser 1987, 285), and are 'bearers and maintainers of cultural and religious values in the face of a dominant, imperialistic West with its hostile challenges to Islam' (Freyer Stowasser 1987, 285).

This 'battle metaphor', used by Qaradawi when discussing the nature of the hijab, had a dual purpose: to win over audiences to his argument through cultural identification (indeed several callers also spoke of the 'war on Islam' waged by the West) and to delegitimise alternative interpretations of the bijab that reject the head covering because such interpretations, in his opinion, serve both the interests of the West and of indigenous supporters of the 'Western model' (or Western way). Consistently drawing on the discourse of war, he said that 'we should leave on the side those countries that cover the face like Saudi Arabia, leave them alone, as for 
other countries we shall win if the woman starts covering her entire body except the face and hands'.

In contrast to his lenient position towards countries and positions that call for covering the face, Qaradawi is highly critical and dismissive of this anti-covering position, calling it a 'problem' created by 'those who want to strip women naked'. Indeed, Qaradawi deployed the 'war on hijab' (and by extension on Islam) metaphor in order to re-set the terms of the debate on hijab conveniently and to avoid discussion of the anti-covering view. By invoking the threat of the West on Muslim women (exemplified by 'unveiling' or 'nakedness'), he positioned this less restrictive view on hijab beyond acceptable, consensual religious and political discourses in the Arab-Muslim world. From his self-declared 'centrist' Islamic position or 'way', he preferred instead to engage the more restrictive but ideologically less problematic (because equally orthodox) position calling for the total covering of women, found at the other end of the definitional spectrum.

In sum, this ideational and textual analysis, at the micro-level, of the main linguistic strategies used by Qaradawi in his discussion of hijab showed how grammatical and lexical strategies, in addition to metaphor, were used in order to privilege a specific (orthodox) definition of the bijab. More specifically, this 'mental picture of reality' (Hallyday 1985, 101), as expressed through language, was based, first, on the dual linguistic strategies of hiding human agency when Qaradawi was defending his own interpretation and discrediting, through linguistic negative framing and distancing devices, those who have an alternative, less restrictive interpretation of the bijab. Moreover, by deploying the 'battle' metaphor when discussing the bijab, Qaradawi shifted the parameters of the exegetical debate on the bijab initially set by the host of the 1998 episode (i.e. to cover the hair or not), strategically repositioning it instead within the confines of Islamic orthodoxy (i.e. to cover the face or not).

\section{A Brief Macro-level Analysis of the Hijab-related Episodes}

We have seen so far how a critical discourse analysis at the micro-level of the bijabrelated episodes from $A$-Sharia wal Hayat was able to show the interplay between grammar and vocabulary at the simple sentence level on the one hand, and dominant religious discourses on the Muslim dress code on the other, and the consequent de-legitimising of progressive, non-orthodox interpretations of the bijab. A brief macro-level analysis that looks at each of these episodes in their totality (i.e. as a superstructure with a global organizing principle), and examines the main topics and themes included in addition to the hierarchies of voices, confirms the results of the micro-analysis. To start with, the main themes of each episode (including selected title and sub-sections of the episodes) reflect 
Qaradawi's own views on the bijab ('the secular attack on bijab', 'pressure on Muslim women in the West to uncover', 'reasons for Western meddling with the specificities of Islam', 'Al-Azhar's lax response to the French ban', and so on), and are almost exclusively explored through his dominant mediating voice as main and only guest. Moreover, the hosts in these episodes openly took sides, 'reporting' on alternative views of reality in ways that echoed Qaradawi's views. For instance, host Ahmad Mansur in the 1998 episode framed anti-bijab voices negatively through his lexical choice (as we have already seen). Similarly, host Maher Abdallah openly expressed his indignation at the ban of the head covering in France by referring to the latter as 'a culture that flaunts its superiority over bumankind because it is based on pluralism' (21 December 2003).

More importantly, the single-guest set up/superstructure of this religious talk show precludes the possibility of debate and interplay among competing discourses on the bijab as is the case in political talk shows on Al-jazeera, and favors one particular religious voice over all others (i.e. Qaradawi's). This intentionally non-adversarial set up is reinforced by a 'guest-friendly' interviewing style that seeks the religious/authoritative knowledge of a venerated guest rather than to provoke him in an attempt to boost ratings. Even the opening and closing sequences are accompanied by soft, almost soporific music that sets the overall serious, sober and non-sensationalist mood of the show. Al-Jazeera's construction of Qaradawi as a pre-eminent, authoritative religious voice is further evidenced by his framing/presence in other generalist talk shows when dealing with religious issues. This was the case in one episode of Lil Nisa' Faqat (For Women Only) about the Muslim face covering or niqab, where the title and main topic interestingly reiterated Qaradawi's framing of the veil issue in A-Sharia wal Hayat episodes (i.e. covering the face or not, as opposed to covering the hair or not). In this episode on the face covering or niqab, female host Luna A-Shibl, in an attempt to close the debate among the female participants (one of whom is Dean of Islamic Studies at $\mathrm{Al}$-Azhar religious university) on whether or not there is a scriptural foundation for covering the face, introduced a short taped interview with Qaradawi as follows: '...to end the discussion about the legal justification [al-hokm a-shar'] about the niqab issue, dear guests, follow with us this report with the honourable doctor (i.e. PhD) Sheikh Youssef Qaradawi' (27 September 2004, emphasis mine).

In sum, A-Sharia wal Hayat, as a religious talk show, is set up a priori, both structurally/formally and thematically, to put forth one specific definition of religious reality and to reproduce dominant, male-centered, fairly orthodox interpretations of Muslim Scriptures.

As such, the overall picture that emerges thus far from all bijab-related episodes on this show with Qaradawi is one of a fairly 'stable' structure within Al-Jazeera's media practice (Fairclough 1995, 30). This picture, moreover, is a far cry from the 
one that emerges from the political talk shows that have conferred on Al-Jazeera its unique status as a major critical voice and as a platform for the opinion and counter-opinion in the stale Arab broadcasting landscape ${ }^{8}$.

\section{Religious Discourse and Talk Shows: Some Methodological and Theoretical Reflections}

The picture of stability as evidenced by the present analysis of the bijab issue on $A$ Shari'a wal Hayat, which makes the phrase 'religious debate' in this show sound like an oxymoron, may not be as stable as it first appears. Fairclough warns against the limitations of media analysis that is restricted to the study of the local/global levels of analysis. In his view, as powerful as this integrated framework for analysis may be, it fails to account for the diversity, complexity and heterogeneity of media practices, and for the relationship between changing media discourse practices and wider social and cultural changes (Fairclough 1995, 30-33). A more elaborate analysis is needed - one that reflects 'areas of variability and instability as well as areas of stability' and where analysis of the local and global levels, for instance, can be 'mapped on to analysis of the institutional and wider social and cultural context of media practices' (Ibid, 33).

Without dismissing Fairclough's important call for an extended multi-leveled analysis, through the use of the bijab issue as a case study, however, I would argue first that one need not necessarily go beyond the micro and macro levels of analysis when studying A-Sharia wal-Hayat in order to detect areas of instability within this television show. The talk show, as programme type, has its own structural exigencies and demands, which can work to subvert the very attempt to present dominant religious ideology as being commonsensical (i.e. monolithic, universal and God-sent). A-Sharia wal Hayat, as we have seen, is set up structurally and thematically in opposition to other talk shows on Al-Jazeera, in order to promote specific definitions of religious reality, at the expense of progressive or feminist definitions. As such, its aim seems to be less geared toward debating religion (and Islamic shari'a), than to promoting specific, mainly orthodox views on gender and Islam. The fact that Qaradawi is hosted alone on at least half of all episodes aired since 1998 is further evidence of this desire to shun debate with proponents of non-orthodox views on religious issues. However, as one of the oldest shows running on Al-jazeera, and one that seeks to offer religious expertise on a vast array of social, health, economic, and political topics that no religious expert can conceivably and single-handedly cover, it would seem to be bound to host a variety of guests. These guests probably handpicked to promote a mainly orthodox view of Shari'a and life, will quite expectedly speak 'commonsensically' in the name of an immutable view of Islam. However, this ideological strategy of 'containing' or 'closing' religious debate can work effectively only if a single 
interpretation of Islamic Scriptures actually exists, or, failing this, if it is possible to host only one single guest on all episodes, who can repeatedly claim that such an interpretation exists. Neither is this (or can this be) the case on A-Sharia wal Hayat. First, there is indeed no 'single Islam' out there, a fact attested to by the mere existence of a variety of established, orthodox, and often conflicting schools of Islam ${ }^{9}$. Second, as already argued, the single guest set up with the same religious expert appearing every week (e.g. Qaradawi) cannot possibly be maintained for several years in a row. Thus, I would argue, the dominant, orthodox religious discourse privileged on A-Sharia wal Hayat may end up being subverted from within, undermined by the very generic format (i.e. live religious talk show with interventions by callers) which is supposed to maintain it. Indeed, contradictions within dominant ideological discourses on Islam on this show - contradictions which expose the 'commonsensical' veneer of these discourses - have been detected on at least two analytical/contextual levels in the bijab-related episodes of A-Sharia wal Hayat. First, as we have seen in the local analysis of the episodes with Qaradawi, the sheikh ended up, at some point during the interview, contradicting himself (ideologically and theologically). When confronted with a question about progressive interpretations of hijab by his 'friendly' host, he tried to defend his own 'commonsensical' definition of the Muslim dress code by conceding that it was actually the result of 'consensus', knowing that he had asserted earlier that is was 'clear in the Qoran' (and therefore not in need of consensus about its meaning).

Second, contradictions within dominant religious discourse become more glaring when looking globally at other, bijab-related, episodes of the same show, which hosted other (orthodox) guests. In one such episode, sheikh Ahmad al-Kabisi supported a quite similar definition of the hijab to Qaradawi's, and asserted that this definition 'is a given in Islam'. He also rejected the niqab (i.e. total covering) because it is not clear in Scriptures, and is instead merely the result of 'consensus'. This religious scholar then discredited the jurisprudential concept of consensus, because, as he put it, 'consensus is a myth' and 'whoever speaks of consensus is a liar'. Both his definition of bijab, and that established by Qaradawi, were challenged by ultra-conservative male and female callers, who were dissatisfied with these 'permissive' views on the Muslim dress. Interestingly, these callers justified the total covering of the face (or niqab) as being clearly scriptural, and cited as evidence those same verses that Qaradawi cited in 1998 to legitimise his opposing views on the Muslim dress code. At some point in this specific episode, the host, Maher Abdallah, tried to intervene and end the argument, reminding viewers that interpretation has indeed always been part and parcel of Islamic jurisprudence, that each of these interpretations is bound by its socio-historical context, and that religious scholars should never collapse their words with those of God: 'he should not say 'this is God's opinion'. He must say this is the view of Islam the way I understand it'! (5 September 1999) ${ }^{9}$. 
In sum, the picture that emerges when another episode from the same religious talk show is considered in the analysis, leads to a more complex picture than that formed when only those bijab-related episodes with Qaradawi are analysed. This approach undermines the stability of the representation of 'commonsensical' dominant views on gender and religion in $A$-Shari'a wal Hayat ${ }^{10}$. Indeed, the above-mentioned examples from the episode hosting Al-Kabisi exposes, however indirectly, internal contradictions and the 'constructedness' of dominant religious discourses within Sunni Islam. This is the case because one of the guests, himself a prominent religious scholar, has questioned 'consensus' (an ideological/theological construct used by Qaradawi to defend his version of the hijab); because various participants (guests and callers) gave contradictory interpretations of the Muslim dress code, each claiming separately that he/she is correct because it is 'clear in the Qoran'; and finally because the only way to reconcile all these differences was offered by the host himself who explained that there is no such thing as a single interpretation of Islam. The apparent stability of this religious talk show might further be undermined when more contextual layers are added to the analysis of religious discourse on Al-Jazeera. I would like to mention here, by way of example, another talk show episode on Al-jazeera, which also dealt exclusively with the Muslim dress code. As one of the main guests on this episode of Lil Nisa' Faqat, a liberal female professor and activist openly dared everyone on the set (the host and other two female guests) to cite 'one clear qoranic verse that states that the bijab is Islamic' (3 June 2002).

As all these few examples related to the bijab show, each additional contextual layer can bring a new (often contradictory) dimension to the ideological analysis carried out at the micro-and global levels of analysis, first within one and the same show (A-Shari'a wal Hayat), then within a single programme type in a media institution (the Al-jazeera talk shows in this case).

This observation regarding 'context(s) of analysis' raises methodological and theoretical questions when assessing discursive practices and discursive change on television talk shows. One such question is related to the difficulty of deciding what is 'text' and how many layers of context discourse analysts need to take into account in order to properly study 'text in context'. As far as the present study is concerned, one should ask whether generically distinct segments (e.g. interviews, reports, phone calls, vox-pop, etc) within a single talk show episode should be considered to be a text, and the entire episode the context requiring a macro-level analysis. Or is each complete episode a text that needs to be seen in context (i.e. in relation to all other episodes of the same show). Would a better account of context also include other talk shows broadcast by the same station? Indeed, 'context', especially when intertextuality is factored in, is quite infinite and amorphous, having no clearly delineated beginning or end. As Cicourel adequately puts it: 
a nagging issue which undoubtedly remains for many readers is the familiar one that an infinite regress can occur whereby the observer presumably must describe 'everything' about a context. Such a demand is of course impossible to satisfy because no one could claim to have specified all of the local and larger sociocultural aspects of a context. Observers or analysts, like participants in speech events, must continually face practical circumstances that are an integral part of research of everyday living $(1992,309)$.

Though analysts may have to make practical decisions as to how many contexts need to be included in discourse analysis, it should be born in mind that every contextual level added to the study of media discourse may entail a different conclusion regarding the extent to which a media outlet is reproducing or challenging dominant discourses in society - a task at the very heart of the critical discourse analysis endeavour.

\section{Concluding Comments}

This paper set out to answer the following general questions: to what extent is $\mathrm{Al}$ Jazeera's religious talk show a forum for 'the opinion and the other opinion', the way the same station's flagship political talk shows are? And to what extent can it be said that Al Jazeera is heralding a new era of discursive (religious) pluralism in the satellite realm? Using the issue of the hijab as a case study, and based on a discourse analysis at the micro and macro level of all bijab related episodes from $A$ Sharia wal Hayat, it can be concluded that the show is neither set up structurally to live up to Al Jazeera's motto, neither is it really intended to do so. According to this satellite broadcaster, and in tune with the larger socio-historical context of the Arab world, religion seems to be set apart from politics, occupying a 'sacred position' distinct from more earthly day-to-day politics.

It may indeed be more adequate to describe A-Sharia wal Hayat as a show meant to promote 'the opinion and the same opinion' of orthodox Sunni Islam, at least as far as the bijab is concerned. Paradoxically, as we have seen, the live talk show genre, however, does not seem to be the television format best suited to carry out this kind of 'ideological work'. Orthodox Islamic discourse in the Arab world, with its anti-rationalist, authoritarian streak, is premised on an ideological collapsing of Scripture with interpretations of Scripture, thus achieving a 'naturalisation' of particular definitions of reality. To question these commonsensical definitions amounts to questioning the word of God, an unthinkable deed to pious Muslims. A-Sharia wal Hayat, generically, as a programme type, is making it possible, however unwillingly or indirectly, to expose the non-universal, temporal nature of dominant religious discourses and to confront its viewers with the realisation that there is more to religious dogma than meets the eye. Herein lies perhaps its saving grace. 


\section{Notes}

${ }^{1}$ Muslim religious scholars, whether conservative or progressive, agree that the term 'bijab' commonly used to refer to the Muslim headscarf is a misnomer, and that its original meaning, as used in the Qoran, actually refers to a physical separation, curtain, or barrier, and is never used in connection with clothing. For details, see Mernissi (1991, 86-87) and Freyer Stowasser (1997). Qaradawi and other religious scholars who appear on A-Shari'a wal Hayat also concur that the qoranic term 'bijab' is incorrectly used to refer to the Muslim headscarf (see $A$ Shari'a wal Hayat episodes aired on 17 May 1998 and 5 September 1999).

2 The total number of bijab-related episodes studied for this article is eight: five from A-Shari'a wal Hayat ('The bijab between religion and tradition' with Qaradawi, 17 May 2005; 'women's issues' with Qabisi, 5 September 1999; 'the liberation of women in the Arab world' with Qaradawi ,5 March 2000; 'The consequences of banning the bijab in France' with Qaradawi, 21 December 2003; and 'women's political eligibility' with Qaradawi, 20 March 2005); and three from Lil-Nisa' Faqat ('The hijab: political symbol or basic right?', 3 June 2002; 'The banning of the bijab in French schools', 22 December 2003; and 'Women's niqab (face covering) in our Arab societies', 27 September 2004). For the local and textual analysis, only the transcripts of those episodes form A-Shari'a wal Hayat hosting Qaradawi were analysed. All transcripts were downloaded from Al-jazeera's Arabic website.

3 In this paper, Muslim scholars who put forth alternatives to the orthodox interpretations of the Muslim Scriptures will be, out of convenience, referred to as 'progressive', knowing that other terms have been used to refer to them (e.g. 'liberal', 'critical', and so on.). Though many such scholars reject the use of any labels to refer to their alternative exegesis, some adopt willingly the term 'progressive', even if they find it problematic (Safi 2003, 17-18).

${ }^{4}$ All translations of the qoranic verses used based on A. Youssef Ali's original translation (1933).

${ }^{5}$ It is worth noting here that the New Testament is, by comparison, very clear concerning what a Christian woman should cover. In his epistle to the Corinthians, Saint Paul explicitly forbids women from showing their hair, stating that if a woman does not cover her head, she should have her hair cut off (Corinthians 11:6).

${ }^{6}$ Epithets, Hallyday writes, 'may be an objective property of the thing itself; or it may be an expression of the speaker's subjective attitude towards it [...]. There is no hard and fast line between these two' $(1985,163)$.

${ }^{7}$ From a grammatical point of view, as Hallyday explains, constructions such as 'everyone knows that...' or 'all authorities on the subject are agreed that...' etc. express modality and basically mean 'I believe'. Such representations of modality indeed allow speakers to hide the fact that they are actually expressing their 
opinion (334). According to Barlas, this 'doctrine of consensus', ideologically, served the interests of the religious establishment by conveniently collapsing Scriptures (Qoran and Hadith) with the socio-political interpretations put forth by this establishment throughout Muslim history (2002).

${ }^{8}$ By way of contrast, see episode of The Opposite Direction (5 May 1998) where Egyptian feminist Nawal Saadawi, in answer to the other guest, an ultraconservative religious scholar, asserts that some interpretations allow for not covering the hair. She was supported by host Faysal Al-Qasem, who agreed that 'there is nothing that calls for covering the face or hands anywhere in religion, not in the Qoran, or the Sunna or anywhere else...'

9 Commenting on the impossibility of any final interpretation of Islam, Abdul Karim Soroush says that 'Islam is but a series of interpretations of Islam, just like Christianity is but a series of interpretations of Christianity' (translated by author) (Benzine, 2004, p. 6).

10 To what extent viewers perceive and accept (or negotiate) these inherent contradictions in dominant religious discourse on A-Sharia wal Hayat remains to be determined by an analysis of viewers reception -an important aspect of critical discourse analysis of the media not dealt with in this study (Fairclough 1995).

\section{References}

Ahmed, L. (1992) Women and Gender in Islam, New Haven: Yale University Press. Al-Ghul, A. (2004) Afouan Sabeeh Al-Bukharee, Beirut: Dar Al-Mahajja Al-Bayda. Al Shammari, S. (1999) The Arab Nationalist Dimension in Al Jazeera Satellite Channel: A Case Study of the Opposite Direction, Doha: Dar Al Shark.

Augustinos, M., K. Tuffin and D. Every (2005) 'New Racism, Meritocracy and Individualism: Constraining Affirmative Action in Education', Discourse \& Society, 16(3): 315-340.

Baraka, I. (2003) Al-Hijab: Rou'ya Asriya, Damascus: Dar Kiwan.

Barlas, A. (2002) Believing Women in Islam: Unreading Patriarchal Interpretations of the Qur'an, Austin: University of Texas Press.

Benzine, R. (2004) 'Une Modernite Islamique', Les Nowveaux Penseurs de l'Islam, Special edition Le Nouvel Observateur, Hors Serie, April/May, pp. 6-7.

Cicourel, A. (1992) 'The Interpretation of communicative Contexts: Examples from Medical Encounters', in A. Duranti and C. Goodwin (eds.) Rethinking Context, Cambridge: Cambridge University Press, pp. 291-311.

Clarke, L. (2003) 'Hijab According to the Hadith', in S. Alvi, H. Hoodfar, and S. Mc Donough (eds.) The Muslim Veil in North America: Issues and Debates, Toronto: Women's Press, pp. 214-286.

Dabbous-Sensenig, D. (2005) " "Lost in Translation" dans le Monde Arabe' (English original: 'Lost in translation? The concept of public service broadcasting in the Arab World'), in J. Bourdon (ed.) Une Television Sans Service Public? Paris: National Audiovisual Institute (INA), pp. 135-143. 
Deacon, D., M. Pickering, P. Golding, and G. Murdock (1999) Researching Communications, London: Arnold.

El-Nawawy M. and I. Adel (2002). Al-Jazeera: How the Free Arab News Network Scooped the World and Changed the Middle East, Cambridge: Westview.

Esposito, J. and J. Voll (2001) Makers of Contemporary Islam, Oxford: Oxford University Press.

Fairclough, N. (1995) Media Discourse, London: Arnold.

Fakhry, M. (1997). Islamic Phliosophy, Theology and Mysticism: A Short Introduction. Oxford: Oneworld Publications.

Freyer Stowasser, B. (1997) 'The Hijab: How a Curtain Became an Institution and a Cultural Symbol', in A. Afsaruddin and A.H. Mathias Zahniser (eds.) Humanism, Culture, and Language in the Near East, Winona Lake, Indiana: Eisenbrauns.

Gill, A. and K. Whedbee (1997) 'Rhetoric', in T.A. Van Dijk (ed.) Discourse as Structure and Process, Part I, London: Sage Publications, pp. 157-184.

Hajjaji-Jarrah, S. (2003) 'Women's Modesty in Qur'anic Commentaries: The Founding Discourse', in S. Alvi, H. Hoodfar, and S. Mc Donough (eds.) The Muslim Veil in North America: Issues and Debates, Toronto: Women's Press. pp. 181- 213.

Hall, S. (1995) 'The Rediscovery of "Ideology": Return of the Repressed in Media Studies', in O. Boyd-Barrett and C. Newbold (eds.) Approaches to Media: A Reader, London: Arnold, pp. 354-364.

Halliday, M.A.K. (1985) An Introduction to Functional Grammar, London: Edward Arnold.

Hamid Abu Zeid, N. (2000) Dawaer Al Khauf, Beirut: Al Markaz Al-Sakafi AlArabi.

Khalaf Allah, M.A. (1977) Dirasat fil-Nuðum wal-Tashari' at al-Islamiyya, Cairo: Maktabat al-anglo al misriyya.

Masterman, L. (1985) Teaching the Media, London: Routledge.

Mernissi, F. (1991). The Veil and the Male Elite: A Feminist Interpretation of Women's Rights in Islam, Reading, Massachussets: Persus Books.

Miles, H. (2005). Al-Jazeera: the Inside Story of the Arab News Channel That Is Challenging the West, New York: Grove Press.

Qaradawi, Y. (2001) An-Niqab Lel-Mar'a, Beirut: Ar-Risala.

Shadid, A. (2003) 'Maverick Cleric is a Hit on Arab TV', Washnigton Post, 14 February 2003, available at http://www.washingtonpost.com/ac2/wpdyn?pagename $=$ article \&node $=\&$ content $I d=A 5496-$ 2003Feb13\&notFound=true. (accessed 23 January 2006).

Shahrour, M. (1990) Al-Kitab wal-Qur'an, Dasmascus: Al-ahali.

Shahrour, M. (2000) Nabwa Usul Jadeeda Lil-Fiqh Al-Islami, Damascus: Dar Al-Ahali Lil-Nashr. 
Smith, J. (1985) 'Women, Religion and Social Change in Early Islam', in Y. Yazbeck Haddad and E. Banks Findly (eds.) Women, Religion, and Social Change, Albany, New York: State University of New York Press, pp. 19-36.

Tileaga, C. (2005) 'Accounting for Extreme Prejudice and Legitimating Blame in Talk about the Romanies', Discourse \& Society, 16(5): 603-624.

Titscher, S., M. Meyer, R. Wodak, and E. Vetter (2000). Methods of Text and Discourse Analysis, London: Sage Publications.

Youssef Ali, A. (1933) The Holy Qur'an; Text, Translation, and Commentary, Beirut: Dar Al-Arabya.

Zayani, M. (ed.) (2005) The Al Jazeera Phenomenon: Critical Perspectives on New Arab Media, London: Pluto Press.

Zayani, M. (2005) 'Al Jazeera and the Vicissitudes of the New Arab Mediascape', in M. Zayani (ed.) The Al Jazeera Phenomenon: Critical Perspectives on New Arab Media, London: Pluto Press, pp. 1-46.

Zeydan, A. (2004) Al-Libas wa-Zeena fil Islam, Beirut: Ar-Risala. 